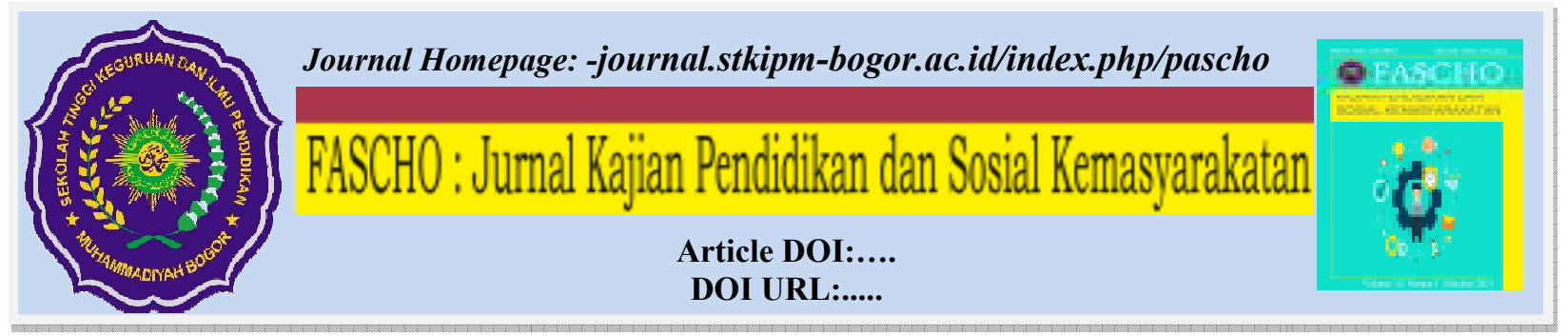

\title{
DEVELOPING ONLINE ASSESSMENT FOR JUNIOR HIGH SCHOOL STUDENTS USING PROPROFS DURING THE COVID19 PANDEMIC
}

\begin{abstract}
Rizdika Mardiana $^{1}$, Dewi Sri Ayu Ramdini ${ }^{2}$, Filzanadilla Dwi Putri ${ }^{3}$, Muhamad Nurdin ${ }^{4}$, Radisti Aulia Zhahra ${ }^{5}$, Siti Nur Annisa ${ }^{6}$, Yulia Setianingsih ${ }^{7}$

English Education Department, STKIP Muhammadiyah Bogor

mardianarizdika@yahoo.com, dewiayuuramdhini@gmail.com, filzanadilladwptr@gmail.com, 1999muhamadnurdin@gmail.com, zhahra23radisti@gmail.com,nurannisa137@gmail.com, setianingsihyulia7@gmail.com
\end{abstract}

\section{Manuscript Info}

Manuscript History

Received: 03 April 2021

Final Accepted: 01 Oktober 2021

Published: 10 Oktoberl 2021

Key words:- online learning, online assessment, Proprofs

\section{Abstract}

The covid-19 virus pandemic has made the world of education change the learning system, from face-to-face learning to online learning. This study aims to develop an online assessment to test students' abilities on the material that has been given online. Interviews with English teachers and collecting documents from the internet are data collection techniques used in this study. Some of the steps that are taken to obtain the results of online assessment development on grade 7, 8, 9 are: (1) The process of reviewing the curriculum and textbooks so that the scope of the questions is determined, namely core competence and basic competence for grades 7, 8, 9. (2) Making questions based on the grid using the Proprofs application. (3) Making an answer key. The making of this answer key is carried out simultaneously with the second stage. The weaknesses and strengths of Proprofs used in creating and developing online assessments are the results of this study.

\section{INTRODUCTION}

The development of highly advanced technology in the modern era allows various activities to be carried out quickly and efficiently. Technological developments have given a lot of influence on our way of life, one of which is in the field of education with the use of e-learning in learning activities at schools, colleges, courses, and even communities. E-learning has been a solution for the world when corona virus disease (Covid-19) started to spread all over the world. In late January 2020, a global health emergency state was announced by the WHO emergency community as Covid-19 was 
confirmed as its cases have been increasing internationally (McAleer, 2020; Velvan and Meyer, 2020). Covid-19 has spread in all continents, but Antarctica as of 20 February 2020. Latest news on Covid-19 has overloaded worldwide mass media everyday in 2020 (McAleer, 2020).

The disease started to enter Indonesia in March 2020 and since then the case has increased significantly. Therefore, the Indonesian Minister of Education and Culture has instructed schools to carry out online learning since March 17, 2020 for areas affected by COVID-19 (Mendikbud, 2020b). Immediately after that, the Minister of Education and Culture of the Republic of Indonesia ordered all education units to carry out online learning starting March 24, 2020 in line with the widespread spread of COVID-19 and maintaining the health of students, teachers, and all education personnel (Mendikbud, 2020a). This policy guides students to study from home and teachers to work from home as well. This completely replaces face-to-face learning in classroom settings to online learning which may last until the end of the semester due to the COVID-19 pandemic. This is a new challenge for students and teachers to carry out online learning.

Assessment and evaluation of learning is carried out in current conditions done at home using online-based assessments. With the availability of technology that has currently developed, the application of online assessment is very possible with the presence of internet network facilities. However, unstable internet connection makes students or even teachers havedifficulty in delivering material or in listening to the material that is being taught. The difficulty also comes to the way teachers check their students' understanding on the material that has been taught. Online assessment can be used to assess what students get at the end of the learning activities. It can be done at any time in a day. If the internet connection is unstable, students could try to do it another time. However, teachers need more knowledge to make and develop online assessment. This paper finds out how to make and develop online assessment to assess students. The question that arise is "How do teachers create and develop online assessment?" 


\section{LITERATURE REVIEW}

Because teaching and learning always try to adapt to technological advances, according on Brown, Race and Bull(1999), at first, online assessments are basicallytransformed students' assessment from paper to screen assessments. Test objectivevarieswidely as well as styles of testing. Behavioral experts recommend teachers to do self-examination and provide formative feedbackregularly. While cognitive experts have developed gradual questions to take values beyond the memory of learners. This aims to test the extent to which the learning outcomes are upgraded to a higher one.

In fact, there are several benefits of online testing that cannot be done in person or using paper and pencil tools. First, online testing can be prepared in a more flexible way, both in terms of time and place. Second, the choice of method in making the questions can be arranged automatically, such as the order of the questions or the series of answers provided for the questions that match the choice. Third, online assessment allows the teacher to offer students the opportunity to rework the problem. Teacher can provide feedback to students, such as scores or detailed assessment results according to the right or wrong answers. Teacher needs to direct or provide instructions for students to take or do online testing (Spivey and McMillan, 2014).

Although there is no significant difference in test scores or final scores between classroom and online (Ledman,2008,Neuhauser,2002;Schmidt,2011). There are several things that must be considered when assessing students online.Students must be responsible for following the online learning process, for example entering online rooms on time and taking learning seriously. In online learning, teacher needs to be creative so that the learning process is not only in one direction. Teacher also need to create a learning atmosphere that is not boring so that students can be more active in class and get used to use technology as a learning medium.In both online and traditional assessment learning objectives, assessment and feedback methods must be clearly defined. Assessment methods must be in accordance with the specified competencies (Gaytan,2004). 


\section{METHOD}

Some documents namely curriculum and syllabus were used as the data source of this study. Supporting data was obtained from an interview with English teachers. Basic competencies and core competencies taken from curriculum and syllabus were the primary data and teaching materials taken from the interview with teachers were the supporting data. Then, the data were investigated by document analysis. The data validity test was done by triangulation. Primary and supporting data taken from English teachers were cross checked with both data from the internet. Interactive analysis was done as a data analysis technique consisting of some steps namely reduction, presentation, and making conclusions.

The online assessment was made with design options using Proprofs for primary and junior secondary levels. Proprofs is a software that can be used to create IT-based learning evaluation programs. Proprofs provides several products in the form of online applications, such as: Quiz, Training, Knowledge Base, Survey, Simple Project, Live Chat, Flashcards, Brain games, Polls. Proprofs is a website that can be used as a learning tool suitable for making online assessments with various features. In addition, it is also useful for educators to take measurements quickly, as well as being fun and interesting for students.

\section{RESEARCH RESULTS AND DISCUSSION}

The development of online assessment that was based on learning materials for grades 7,8 and 9 junior high schools through several steps including: a) reviewing the curriculum and teaching materials so that the scope of questions can be determined; b) Formulating specific instructional goals; c) create a grid or blueprint for the assessment tool; d) writing questions based on the grid; e) create and determine the answer key to the question. 


\section{a. Reviewing the curriculum and teaching materials}

In this step, curriculum and teaching materials of each class were reviewed. Core competence and basic competence were selected from the curriculum. The selected core and basic competence of each class are presented below.

- Core competence and basic competence of $7^{\text {th }}$ grade

\begin{tabular}{l|l}
\hline Core competence & Basic competence \\
\hline $\begin{array}{l}\text { Respect and live up to the teachings of his } \\
\text { religion }\end{array}$ & $\begin{array}{l}\text { Understand the social function, text } \\
\text { structure and linguistic elements of the } \\
\text { instruction text, short notice, } \\
\text { warning/caution, according to the context } \\
\text { of their use. }\end{array}$ \\
\hline $\begin{array}{l}\text { Appreciate and live honest behavior, } \\
\text { discipline, responsibility, care (tolerance, } \\
\text { mutual cooperation), courteous, self- } \\
\text { confidence, in interacting effectively with } \\
\text { the social and natural environment within } \\
\text { the range of association and existence }\end{array}$ & $\begin{array}{l}\text { (instruction), sign/sign } \quad \text { (short notice), } \\
\text { written very short and simple. }\end{array}$ \\
\hline $\begin{array}{l}\text { Understand knorbal and } \\
\text { conceptual, and procedural) based on his } \\
\text { curiosity about science, technology, art, } \\
\text { culture related to visible phenomena and } \\
\text { events. }\end{array}$ & \\
\hline $\begin{array}{l}\text { Trying, processing, and presenting in the } \\
\text { realm of the concrete (using, unraveling, } \\
\text { arranging, modifying, and making) and the } \\
\text { realm of the abstract (writing, reading, } \\
\text { counting, drawing, and composing) in } \\
\text { accordance with what is learned in school } \\
\text { and other sources that are the same in } \\
\text { perspective /theory. }\end{array}$ & \\
\hline
\end{tabular}


- Core competence and basic competence of $8^{\text {th }}$ grade

\begin{tabular}{|c|c|}
\hline Core competence & Basic competence \\
\hline $\begin{array}{l}\text { Respect and live the teachings of the } \\
\text { religion they adhere to as well as Respect } \\
\text { and live up to honest, disciplined, polite, } \\
\text { confident, caring and responsible behavior } \\
\text { in interacting effectively in accordance } \\
\text { with the development of children in the } \\
\text { environment, family, school, community } \\
\text { and natural environment around, nation, } \\
\text { country, and regional areas. }\end{array}$ & $\begin{array}{l}\text { Applying social functions, text structure, } \\
\text { and linguistic elements of oral and written } \\
\text { interpersonal interactions that involve } \\
\text { asking and expressing opinions, and } \\
\text { responding to them, according to the } \\
\text { context of their use }\end{array}$ \\
\hline $\begin{array}{l}\text { Understand and apply factual, conceptual, } \\
\text { procedural, and metacognitive knowledge } \\
\text { at a simple technical and specific level } \\
\text { based on his curiosity about science, } \\
\text { technology, art, culture with insight into } \\
\text { humanity, nationality, and statehood } \\
\text { related to visible phenomena and events. }\end{array}$ & $\begin{array}{l}\text { Compose a very short and simple oral and } \\
\text { written interpersonal interaction text that } \\
\text { involves asking and expressing opinions, } \\
\text { and responding with attention to social } \\
\text { functions, text structure, and linguistic } \\
\text { elements that are correct and in context. }\end{array}$ \\
\hline $\begin{array}{l}\text { Demonstrate the skills of reasoning, } \\
\text { processing, and presenting creatively, } \\
\text { productively, critically, independently, } \\
\text { collaboratively, and communicatively, in } \\
\text { the realm of the concrete and the abstract } \\
\text { realm as learned in school and other } \\
\text { sources similar to the theoretical point of } \\
\text { view }\end{array}$ & \\
\hline
\end{tabular}

- Core competence and basic competence of $9^{\text {th }}$ grade

\begin{tabular}{l|l}
\hline Core competence & Basic competence \\
\hline Respect and live the teachings of the & $\begin{array}{l}\text { Comparing social functions, text structure, } \\
\text { religion they adhere to as well as Respect } \\
\text { and linguistic elements of several oral and }\end{array}$ \\
and live up to honest, disciplined, polite, & written narrative texts by providing and \\
confident, caring and responsible behavior & asking for information related to fairytales, \\
in interacting effectively in accordance & short and simple, in accordance with the \\
with the development of children in the & \\
\hline
\end{tabular}




\begin{tabular}{l|l}
\hline $\begin{array}{l}\text { environment, family, school, community } \\
\text { and natural environment around, nation, } \\
\text { country, and regional areas. }\end{array}$ & context in which they are used. \\
\hline $\begin{array}{l}\text { Understand and apply factual, conceptual, } \\
\text { procedural, and metacognitive knowledge }\end{array}$ & $\begin{array}{l}\text { Apprehending meaning contextually } \\
\text { related to social functions, text structure, } \\
\text { at a simple technical and specific level } \\
\text { and linguistic elements of narrative text, } \\
\text { based on his curiosity about science, } \\
\text { spoken and written, very short and simple, } \\
\text { related to fairytales } \\
\text { humanity, nationality, and statehood } \\
\text { related to visible phenomena and events. }\end{array}$ \\
$\begin{array}{l}\text { Demonstrate the skills of reasoning, } \\
\text { processing, and presenting creatively, } \\
\text { productively, critically, independently, } \\
\text { collaboratively, and communicatively, in } \\
\text { the realm of the concrete and the abstract } \\
\text { realm as learned in school and other } \\
\text { sources similar to the theoretical point of } \\
\text { view }\end{array}$ & \\
\hline
\end{tabular}

\section{b. Formulating Specific Instructional Goals}

Formulating specific instructional objectives is needed to clarify what abilities are expected to students and what should be assessed. Each class uses a different basic competence, so the purpose is different.

- $7^{\text {th }}$ Grade

After studying the signs, it is hoped that students can understand the meaning of signs and also obey the signs that are around them and know the appropriate words when completing sentences.

- $8^{\text {th }}$ Grade

After studying the expressions asking opinion and giving opinions, students are expected to be able to use these expressions in accordance with the context of their use by paying attention to social functions, text structure and correct language elements. 
- $9^{\text {th }}$ Grade

After studying Narrative text, students can understand the setting, where and when this narrative story occurs. Students can also distinguish the place and time from one story to another. Students should be able to distinguish which characters are inappropriate to imitate, and which are exemplary characters.

\section{c. Creating an Assessment Tool Grid}

At this stage, assessment tool grid was created by analyzing the indicators of each class. The detailed grids are presented below.

- $7^{\text {th }}$ Grade

Indicator of each question number is represented in the following table.

\begin{tabular}{l|l}
\hline Indicator & Questions number \\
\hline $\begin{array}{l}\text { Students are able to completea } \\
\text { conversation which is suitable to the } \\
\text { context }\end{array}$ & Questions 1-3 \\
\hline $\begin{array}{l}\text { Students are able to complete a story by } \\
\text { changing the picture using the correct } \\
\text { answer }\end{array}$ & Questions 4\&5 \\
\hline
\end{tabular}

- $8^{\text {th }}$ grade

Indicator of each question number is represented in the following table.

\begin{tabular}{l|ll}
\hline Indicator & Questions number \\
\hline $\begin{array}{l}\text { Students are able to identify expression of } \\
\text { asking for opinion }\end{array}$ & $\begin{array}{l}\text { Questions number 1,3,4,9,10 (Multiple } \\
\text { choice) }\end{array}$ \\
\hline $\begin{array}{l}\text { Students are able to identify expression of } \\
\text { giving opinion }\end{array}$ & $\begin{array}{l}\text { Question number 2,5,6,7,8 (Multiple } \\
\text { choice) }\end{array}$ \\
\hline
\end{tabular}

- $9^{\text {th }}$ grade

Indicator of each question number is represented in the following table. 


\begin{tabular}{l|l}
\hline Indicator & Question number \\
\hline $\begin{array}{l}\text { Presented with a Narrative text, students } \\
\text { are able to determine the equivalent words } \\
\text { to complete the text }\end{array}$ & (question number 1\&2 (Narrative text)) \\
\hline $\begin{array}{l}\text { Students are able to identify detailed } \\
\text { written information contained in narrative }\end{array}$ & (question number 1\&2 (Narrative text)) \\
text & \\
\hline $\begin{array}{l}\text { Students are able to identify detailed } \\
\text { implicit information contained in narrative }\end{array}$ & (question number 1\&2 (Narrative text)) \\
text & \\
\hline
\end{tabular}

\section{d. Making Questions Based On Lattice Using Proprofs}

The first step to take is to visit the proprofs.com website. At the top right there are many menu options, then select the first number (quiz creation). Next, click (get started for free) and create an account using your email. After that you will be redirected to the quiz creation column. Click (create your first quiz) then select (score quiz) to make an online assessment. Then click (create from scratch) and start creating questions and question titles. In the left column there are many choices of questions, choice of types of questions that match the questions that have been made and don't forget to include the answer key. To check the questions before saving, you can select (preview) in the menu column above. After you finish writing the questions, click (finished) and after that the questions that have been created will be shown on the screen. To share a question, click the three dots on the saved question and select send.

\section{CONCLUSION}

It can be concluded that there are some advantages and disadvantages of making online assessment for junior high school students using Proprofs. It is quite easy to make and develop an online assessment using Proprofs. It can be evaluated in real time. Teachers can give various quizzes to students. With online assessments, it can be easier 
to work on questions and score because they can be done anywhere. In addition, online assessments are more practical because they are done by ranking gadgets such as smartphones or laptops that do not require a lot of paper. It also enhances interactivity, have a time and place flexibility, can reach a global audience, and the contents can be updated easily.

In developing an online assessment, it takes quite a long time to make material that fits the syllabus and matches the tools available on Proprofs because it has to match the features with the questions that have been made. In addition, when operating the Proprofs website, there are many advertisements that appear. This is quite disruptive to comfort in making or moving assessments. Because using a free website, the complementary features available are quite limited. To use the full features, it requires expensive fees with a fairly complicated payment process.

\section{REFERENCES}

Brown, S.; Race, P. and Bull, J. (Eds) (1999) Computer Assisted Assessment in Higher Education Staff and Educational Development Series. Kogan Page: London in Francis, A (2006). Theories of Learning and Their Implications for On-Line Assessment. Turkish Online Journal of Distance Educations-TOJDE. Vol. 7, No.1, ISSN 1302-6488

Gaytan, J. (2004). Effective assessment techniques for online instruction. Information Technology, Learning, and Performance Journal, Vol. 23, No.1.

Ledman, R. E. (2008). Comparing student learning in online and classroom formats of the same course. Developments in Business Simulation and Experiential Learning, 35, 351-352.

McAleer, M. (2020). Prevention Is Better Than the Cure: Risk Management of COVID19. Journal of Risk and Financial Management, 13(3) in Atmojo, A.E.P., \&Nugroho, A. (2020). EFL Classes Must Go Online! Teaching Activities and Challenge During Covid-19 Pandemic in Indonesia. Register Journal. Vol. 1, No.1, pp.49-76

Mendikbud.

(2020a).

SuratEdaranMendikbud: PelaksanaanKebijakanPendidikandalamMasaDaruratPenyebaran Corona Virus 
Disease (COVID-19). Retrieved fromhttp://kemdikbud.go.id/main/files/download/51e9b72ef92c6d8

Mendikbud. (2020b). SuratEdaranMendikbud: Pembelajaransecara Daring danBekerjadariRumahdalamRangkaPencegahanPenyebaran Corona Virus Disease (COVID-19).Retrieved fromhttp://kemdikbud.go.id/main/files/download/c5d9f0ec9ff40c6

Neuhauser, C. (2002). Learning style and effectiveness of online and faceto-face instruction. American Journal of Distance Education, 16, 99-113.

Schmidt, M. (2011). Lessons from teaching undergraduate finance online. Proceedings of

Academy of Business Disciplines Annual Meetings, Fort Myers, FL.

Spivey, M. F. and McMillan, J. J. (2014). Classroom versus online assessment. Journal of Education for Business, 89, pp. 450-456.

Velavan, T. P., \& Meyer, C. G. (2020). The COVID $\square 19$ Epidemic. Tropical Medicine and International Health, 25(3), 278-280in Atmojo, A.E.P., \&Nugroho, A. (2020). EFL Classes Must Go Online! Teaching Activities and Challenge During Covid-19 Pandemic in Indonesia. Register Journal. Vol. 1, No.1, pp.49-76 